\title{
DNA portraits: celebrations of the technoself
}

\section{Meaghan Brierley}

Abstract

Keywords

Context
The representation of self and the nature of our identities often converge through technological forms. This study investigates the promotional techniques of seven companies selling DNA portraits, the objective being to uncover how these images derived from laboratory processes are viewed as valid depictions of the self and scientific knowledge. DNA portraits are revealed as the intertwining of technology and identity through celebrations of the technoself.

Images and representations of science and technology; Perceptions of science and technology; Science, technology, art and literature

Advances in the DNA sequencing technologies that contributed to the mapping of the human genome have spurred new directions in science and a new era in medicine [Chial, 2008]. The bioinformatization of society has "allowed new identities, new categorizations, and new forms of social organization to emerge" [Zwart, 2009]. The era has been embraced and furthered by communities of science professionals, yet these identities, characterizations, and social organizations, have also been broadened by other communities and publics, and in so doing, provide new opportunities for the commercialization of science and its processes. People's engagement with these potentials in their daily lives is part of increased access to genomics-based technologies and the available forms they take. One such new product is the "DNA portrait," the visual representation of the DNA sequences behind an individual's genetic traits.

DNA portraits rely on the tools of sequence analysis - the standard tools of molecular biology - that help to establish identity, disease, and ancestry. The results of these standard laboratory procedures are re-envisioned and sold online as the visual representation of people's "unique" genetic characteristics. Such new forms are bound to the creative use of biotechnologies available to interested communities, where processes once financially inhibitory have become more accessible [Zettler, Sherkow and Greely, 2014]. Such endeavours include the rise of do-it-yourself biology [Landrain et al., 2013]; synthetic biology [Hilgartner, 2012]; commercial ventures such as direct-to-consumer advertising of genetic tests [Einsiedel and Geransar, 2009], paternity [Daemmrich, 1998; Levitt, 2001], or forensic evidence [Daemmrich, 1998]; and community research activities such as the promotion of genetic histories like National Geographic's Genographic Project [National Geographic, 2014]. The public's interest in, and access to, 
biotechnologies and the information they produce, are also present here - those curious about the information their genes disclose can pursue information from those able and willing to provide it. Two different trajectories may be evident here however. Understanding the information genes disclose in terms of health and disease, ancestry, or paternity, may be a different use of genetic information from the more playful or artistic initiatives undertaken by commercial companies engaged in representing one's DNA as commercial art. Discussions of genetic surveillance reveal hesitancy and fear in popular conversation [Rosen, 2009]; yet such trepidations can transition to awe, inspiration, and engagement when coupled with art as exploration and critical conversations of science and its use [Walters, 2013]. The rise of the DNA portrait presents an opportunity to explore how individuals are interpreted in the presentation of new genomic products.

In this paper, I briefly review the historical context of portraiture, its connections with technology, and the evolving meanings of identity and representations to locate DNA portraits in this evolutionary trajectory. I present the emerging literature on technoself as part of this context. The subsequent analysis is focused on the promotional approaches of seven companies that produce DNA portraits. I end with a discussion of science and science processes as embedded in the fluidity of the technoself which is neither science nor art, because it is more about communication than reflection, and self-presentation than self-representation [Harrison, 2002; Slater, 1995].

DNA as cultural artifact
The double helix of DNA has become the image epitomizing the biological sciences [Nelkin and Lindee, 1995]. It has also become iconic in popular culture, an image no longer needing spelling out or explanation. When James Watson and Francis Crick proposed the helical structure of DNA, they were both scientists and artists engaged in the processes and art of visualization [Kemp, 2003]. More than 30 years later, processes such as genetic fingerprinting [Jeffreys, Wilson and Thein, 1985], and polymerase chain reaction (PCR) [Templeton, 1992], allow sequences of DNA to be compared and employed to aid in the diagnosis of inherited disorders, biological evidence, identification, and further research. Such processes have also become the foundation of commercial products such as DNA Ancestry and 23andMe and are not without critique. 23andMe's services identify genetic markers correlated with "more than 254 specific diseases and conditions" to "inform people about their health and how to take steps to improve it" [Annas and Elias, 2014], claims that caused the FDA to issue a warning to 23andMe in 2013 to suspend providing health-related genetic tests until the company obtained necessary approvals [FDA, 2013].

Aside from providing biological information, DNA can be further re-engineered into new forms of organisms and new structures through synthetic biology [Schmidt, 2009], or sculpted into new nanoscale sculptural forms [Douglas et al., 2009; LaBean, 2009; Rothemund, 2006; Seeman, 2003]. Using these techniques, DNA is also engineered into bacteria as sculpture [Davis, 1996] and as poetic verse [Davis, 2013]. Engaging with the "wet-biological" techniques of DNA sequencing, artists have critically explored the potentials and challenges of such scientific practices. In this way, DNA as an information medium for art has been the subject of exploration for aesthetic, political and philosophical purposes [Anker and Nelkin, 2004]. For example, Joe Davis and colleagues' Microvenus incorporates 
a sequence of DNA base pairs in the form of a graphic icon representing "woman" into a living strain of bacteria to dispute the gendered omissions of previous messages aimed at communicating with extraterrestrial intelligence [Davis, 1996]. To remind people that techno-scientific systems are constructed, in Latent Figure Protocol (2007-2009), Paul Vanouse reconfigures standard representations of the DNA "Fingerprint" to challenge the notion that it is a "single, unique human identifier" [Vanous, 2009]. To emphasize the importance of committing to "respect, nurture, and love" the new biological lives created, Eduardo Kac's GFP Bunny (2000) (a green fluorescent protein transgenic rabbit), becomes part of an ongoing multidisciplinary dialogue; and Genesis (1999), featuring a sentence from Genesis incorporated into bacteria, questions humanity's supremacy over nature [Kac, 2000]. Paralleling a focus on these examples that explore "the intersections between art, critical theory, technology, and political activism" [CAE, 1987], the Critical Art Ensemble is a collective of media practitioners who create situated works and events that resist a taken-for-granted acceptance of the public's lack of access to biotechnology [Heim, 2004]. The rise of the community biolab and amateur biologists is representative of this interest in an increase in access to biotechnology [Kean, 2011; Newman, 2012; Delgado, 2013]. As an example of the work emerging from these labs, Heather Dewey-Hagborg's three-dimensional models of faces are built from genetic information extracted from items left behind in public places - cigarette butts, hair, chewed gum [Wang, 2013]. Such artwork taps into the potentials of genetic information and identification, but as well, reveals people's trepidation at the potentials of such information [Walters, 2013]. By creating sculptural portraits of the genetic traces we leave behind, Dewey-Haborg's work probes who has the access and ability to interpret representations of individuals from genetic data.

Less representational portraits, such as Marc Quinn's DNA portrait of Sir John Sulston, are by contrast "living." Bacteria act to replicate the DNA of the person represented [Thomas, 2009; Peters, 1999]. Bacteria-produced and reproduced "portraits" also raise topics such as fears of cloning, validity, and the quest for the perfect copy of the "living" through image [Thomas, 2009].

Echoing elements of the artistic work discussed to this point, the DNA portraits presented in this article are most closely related, if not a continuance of, Iñigo Manglano-Ovalle's series The Garden of Delights (1998), featuring chromogenic prints of DNA analyses. Manglano-Ovalle allowed sitters to choose the colours of the prints and then combined information according to varied family groupings [Joselit et al., 2000]. The laboratory processes used by Manglano-Ovalle, as well as the companies featured in this article, are discussed in the next section. The commercial sale of the products of laboratory processes emphasize the popularity of the DNA portrait.

Laboratory processes
DNA portraits depict the result of a laboratory process (agarose gel electrophoresis) that separates DNA strands according to size. Producing a DNA portrait begins in much the same way as other consumer genotyping processes (e.g., ancestry; paternity). Companies providing the service send participants a genetic material collection kit by mail. Participants collect genetic material through a cheek swab (buccal swab), and mail the sample back to the company. Identification is assigned to the sample, and the laboratory process begins: the DNA is isolated, and 
restriction enzymes are used to target specific sequences of DNA, cutting the DNA at a point relative to a particular sequence. The chosen regions are amplified using the process of polymerase chain reaction (PCR) where a few strands of DNA are multiplied millions of times. These are the DNA strands that are sorted by size across the gel, ultimately forming the bands that characterize the DNA portrait. The enzymes and regions each DNA portrait company uses differ, but are founded in known highly variable sequences called variable number tandem repeats (VNTRs); VNTRs are similar across genetic relations, but highly unlikely to be the same for those unrelated. The DNA is then run in a gel, electricity passed through the matrix separating the different-sized DNA bands. As the DNA passes across the gel, the DNA-binding dye that attaches to it is ultimately revealed by a UV transilluminator, and a photo is taken of the band patterns.

The resulting image is digitally refined (e.g. coloured), and printed on a variety of mediums depending on the choices made by the client and what the company providing the service furnishes.

The laboratory processes just described are currently used by the companies producing commercial DNA portraits; such gels are helpful when working with a smaller number of DNA fragments. When working with a large number of genes, DNA arrays are used to assess hundreds of thousands of single-nucleotide polymorphisms (SNPs) in a DNA sample [Hunter, Khoury and Drazen, 2008; Müller and Nicolau, 2005]. Microarrays are powerful systems that monitor how much a set of genes are expressed. It is notable that artists have also transitioned with this technology. For example, Manglano-Ovalle, previously noted for his work with gel electrophoresis in 1998, completed Portrait of a Young Reader in 2006 using microarray as the DNA sampling method [Manglano-Ovalle, 2006]. The differences between the results of gel electrophoresis and microarray are presented in Figure 1.
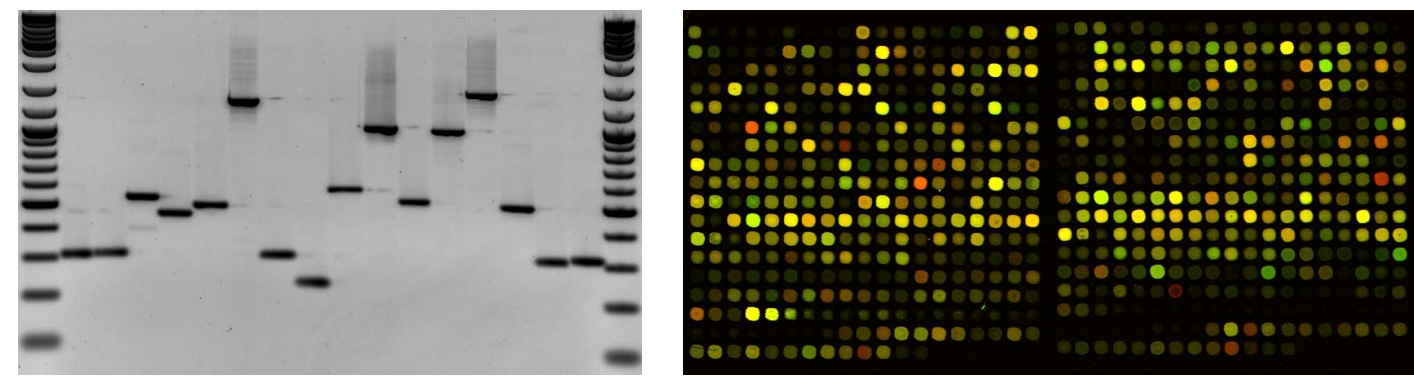

Figure 1. Examples of gel electrophoresis (left) and microarray (right). Gel electrophoresis is the process employed to create the foundation for the images used in DNA portraits. (via Wikimedia Commons: "PCR gel electrophoresis" by Rkalendar [CC BY-SA 3.0]; "a fragment of cdna microarray" by Mangapoco [CC BY 2.5].

Techno-identity and the technoself
Techno-identity, the nature of human identity — how we think of ourselves and how we present ourselves to others - has been mutable over time, changing with changing social mores, religious beliefs, scientific developments, and larger cultural shifts. Changes have also occurred with technological advances:

New technologies reflect society; the study of context collapse and its relationship to self-coherence are fundamental issues in the future of identity 
research to help explain technology's intertwinement with human identity. [Fornaciari, 2013]

The issue of "context collapse" [Marwick, 2011] is one mirrored in on-line environments where the presentation of self is devoid of situational and contextual information and crafted with partly real, partly imagined audiences. In computer-mediated worlds, "the self is multiple, fluid, and constituted in interaction with machine connections" [Turkle, 1995].

Much of the research on technology and identity has focused on how technology has redefined human identity and how humans in turn use technology to reconfigure identities and present the self in new ways, how new interactions develop out of new technological recreations of the self. Such active enactments are explained by an emerging body of scholarship under the umbrella of "Technoself Studies" focusing on investigations of human identity within shifting landscapes of human-technological relationships [Luppicini, 2013].

How might such portraits be regarded? Sigmund Freud argued that major scientific discoveries usually entailed "narcissistic offenses" [Zwart, 2009]. For example, the Copernican revolution removed us from the center of the universe as we knew it; the Darwinian revolution eliminated our separateness from other species. The genomic revolution has dug deeper into our sense of self to reveal - for good or ill - how we think of ourselves and our ties - to family, community, race (and its illusory links). Are DNA portraits another way of celebrating both the uniqueness and fluidity of how we see ourselves? In order to explore this question we ask what promotional tools and approaches are used by companies to entice folks to purchase such art. As Zwart posited, "[a]re the individuals involved the subjects of new practices of Self-formation, or rather the objects of marketing strategies, that is: mere consumers of novel genomic products?" [Zwart, 2009]. To explore this question, we can at least develop some understanding from the framing of DNA portraits by the companies promoting them.

An examination of how, and in what form, companies sell our genetic material to us as DNA portraits provides further insight into what we accept and interpret as valid representations of the overlap between contemporary scientific knowledge and identity.

With the keywords "DNA Art" and "DNA Portrait," popular- and publicly-accessible Internet search engines were used to locate websites dedicated to selling DNA portraits for analysis. Ten websites were found, and seven were further examined for the study: one in Canada, one in the United States, three in the United Kingdom, one in Spain, and one in France. One site was not pursued because its supplier was already included as part of the study (easydna.ca linked to DNA11 as DNA Art supplier); another (expressionsdna.com) produced jewelry rather than the two-dimensional images promoted by the seven companies chosen; and another (iDNAportrait.com) stopped offering its services online during the process of data analysis. One website (yonderbiology.com) underwent a redesign during the study, yet continued to feature two-dimensional DNA portraits as one of 
its product lines, so was included in the research. All of the sites analysed cheek swabs delivered from clients by mail.

The researchers captured and archived each of the websites as PDFs between January and July 2014. All pages with the same root address were included (e.g. www.DNAportrait-site.com, http://www.DNAportrait-site.com/about-us, etc.). The visual and textual information presented by the sites became the unit of analysis to decipher the strategies companies used to sell DNA portraits. The archived sites were coded for visual representations of environments, production processes, genotype options, FAQs, and endorsements.

Seven websites (Table 1) promoted DNA portrait products. Several of the companies also sold other "identity" products (i.e., fingerprint and lip impression images, ancestry information), as well as products featuring DNA portraits such as iPhone covers and clothing; BioPop further offered other biotech artifacts such as the dinoflagellate "Dino Pet" (a "living art" "sculpture"), and the A.C.G.T.: A Complete Genome in Time, (featuring a Mac Mini, flat-screen monitor and genome data programmed to run an individual's complete genome over a one-year time period). DNA Art UK Limited, PlayDNA and DNA Solutions only offered DNA portrait products. The content of this article deals solely with DNA portrait products. Across the purchase process, choices for DNA portraits included materials, colours, the number of people featured (between 1-4), additions such as signatures, and the option to obtain a digital downloadable file. During the purchase process, only a few companies offered a choice of traits "up-front": DNA Art offered the "gender gene" "alcohol gene" "caffeine gene" and "sports gene"; PlayDNA Limited offered characteristics in the categories of "personal" and "sporting" options; and GeneticPhotos promoted examples such as "mathematics," and "sports" options. The other companies did not cite trait choices before payment was made.

This section profiles how the seven websites promoted DNA portraits to potential customers. The results reveal promotions based on both the qualities of the DNA portrait "product" and of the "company." The DNA portrait is promoted as providing a celebration of uniqueness, a celebration of family, and a celebration of self discovery; the companies present qualities such as scientific expertise, an ability to uniquely combine science and art, and an ability to enhance the design and environment aspects.

Table 1. DNA portrait websites analysed for this study.

\begin{tabular}{ll}
\hline Country & Address \\
\hline Canada & DNA11: www.dna11.com \\
\hline France & Helys: www.helys.fr \\
\hline Spain & GeneticPhotos: www.geneticphotos.com \\
\hline United Kingdom & DNA Art UK Limited: www.dna-art.co.uk \\
& PlayDNA Limited: playdna.co.uk \\
& DNA Solutions: www.dnaeffect.com \\
\hline United States & Biological \& Popular Culture, Inc.: www.biopop.com (previously \\
& Yonder biology: The DNA Art Company: yonderbiology.com) \\
\hline
\end{tabular}


Across the websites' texts, DNA portraits are promoted as distinctive in terms of the genetic code they represent, and as a means of self discovery (Table 2). The portrayals of the DNA strands are described as unique to individuals: "The work is inspired by you and created from you" (GeneticPhotos) - DNA strands provide "unique insight" (PlayDNA) about our "unique identity" (Helys). DNA is explained as a unique molecule connected to the people who may purchase a DNA portrait.

Just as the genetic code is presented as a representation of a distinct person, so the art itself is a personal, original masterpiece: "bespoke and unique to you" (PlayDNA). The portraits are described as providing information about "interesting genetic characteristics" that may challenge the purchaser's previous understandings of self. The potentials for self discovery might also include comparing and contrasting one's DNA portraits with other family members', and in the process of comparison, appreciate finding similarity: "seeing similarities with your relatives (which is very cool and fun by the way)" (Yonder biology).

\section{Qualities of the Company: Scientists and Artists; Genetic and Aesthetic Options; and Display Options}

Companies are promoted as collaborations of designers, artists, scientists, artist-scientists, scientist-artists, and scientific and technical laboratories. DNA portrait providers promote working with scientists who create unique methodologies and processes unattainable elsewhere, and artists who use scientists' findings to further customize the genotype portraits. Each company website provides information to potential purchasers about the laboratory, and the post-laboratory processes involved in the creation of the images (Table 3).

Websites promoting DNA portraits feature their completed imaged products in immaculate, unspoiled, couture spaces. DNA portraits connect buyers to upscale kitchens, modern bedrooms and sleek living rooms in monochromatic or bright colour palettes. One company explains "Each of us wants to live in a decor that reflects our individuality. What reflects our identity more precisely, authentically or intimately than our own DNA?" (Helys). Pristine outdoor and indoor environments frame every DNA portrait. Yonder Biology features its work in outdoor landscapes; Biological \& Popular Culture silhouettes its work with palm trees. In one sample, PlayDNA uses an outdoor brick wall background next to hints of garden surroundings. In another it features minimalist, white modern interiors, as do DNA11, and GeneticPhotos. Pristine contemporary interiors are also promoted by DNA Art UK, Helys and DNA Solutions.

Few people are seen in the surroundings. Helys unites couples in its portraits, promoting gifts for Valentine's Day. PlayDNA shows images of families and couples as suggested DNA "personal portrait" clients. Yet the art and the people are not united in living spaces. 
Table 2. DNA Portraits are sold as products that have three qualities: DNA code that is unique to the purchaser; opportunities for self-discovery; and opportunities for celebrating family connections.

\begin{tabular}{l} 
Theme \\
\hline DNA portraits are consistently \\
referred to as "unique" in terms \\
of the DNA strands, and more \\
broadly, the DNA code. \\
Information about the personal \\
characteristics represented \\
are described as defining the \\
uniqueness of individual people \\
and of the "one-of-a-kind" por- \\
traits they have chosen.
\end{tabular}
of Self Discovery.

DNA portraits provide a new way of seeing oneself. They are the masterpiece of "self," where "masterpiece" is defined as singular: "an artist's or craftsman's best piece of work."
Support

"The DNA code is unique to each individual." Yonder biology

"Interpretable art as unique as you." PlayDNA

"No one has the same genetic profile or DNA fingerprinting. This uniqueness is determined by our genes. Genes are nothing more than long sequences written in a code made of DNA bases. The work is inspired by you and created from you." GeneticPhotos

"DNA: A molecule in our image." "What more fitting image than DNA to represent our deepest desire: to be an integral part of Humanity while asserting our unique identity?" Helys

"We make art that is about you. The real you. We're about making art personal. Unique. One of a kind." DNA11

"Most artwork or furnishings is mass-produced and can be found in many shops, our art pieces are bespoke and unique to you. No one shares the same DNA profile as you and this concept is something very personal, very individual \& very you." DNA Effect

“To own a DNA Art UK print is to possess one of nature's own original masterpieces. Unique in its creativity; unique in its artistry. The ultimate portrait of what it is to be not just a human being, but this one special human being. Mysterious, incredible and inimitable." DNA Art

"The masterpiece in you — DNA portraits with meaning." PlayDNA

"Stuart was surprised to discover he has a dormant blue eye gene in his genetic background despite having hazel brown eyes himself. A chat with his mum led to the discovery that his maternal great grandfather had blue eyes, a fact that had remained hidden for three generations behind the more dominant brown gene in his family!" Play DNA

"Display the mysterious story of your life in a modern work of art... unique!" Helys

"If you've chosen the 'Love Gene' to appear on your masterpiece GPORTRAIT, it will appear in lane 9 and no other marker will appear." GeneticPhotos

DNA Portraits Are Family Portraits.

"Our PlayDNA family Portrait is a lasting memory to our daughter." PlayDNA

Family portrait options provide lasting connections between family members. These genotype family portraits introduce genetic similarities and differences between family members.

"DNA: our heritage and legacy"

"If you have your mother's dimples or your father's eyes, it is thanks to your DNA. The magic of DNA lies in the fact that it is what we are today, what we inherited from our parents and what we can pass on to our children." Helys

"From the DNA image we can tell if you are a girl or a boy (no extra charge). Aside from seeing similarities with your relatives (which is very cool and fun by the way), very little can be gleaned from these gel images." Yonder biology 
Table 3. DNA portraits reflect the qualities of a company, its scientist-artists, genetic and aesthetic options, and display contexts.

Theme
DNA Portraits Promote Scient-
ists, Artists and Scientist-Artists
as the Creators of the Images.

Scientists expand their own selfdefinition as creative entrepreneurs.

DNA portrait clients can work with DNA artists to create a bespoke, or custom, visual work.

Occasionally, only scientists can interpret and produce a genetic profile; knowledge is held by one community.

\author{
Support \\ "PlayDNA is a company run by scientists with an artistic streak." \\ PlayDNA
}

"We put our scientific expertise to the job, creating a methodology based on elegant molecular genetic techniques that enables us to create dazzling artwork that can tell your personal genetic story. We believe you cannot get this anywhere else!" PlayDNA

"Yonder's scientists interpret the DNA code and our artists use the interpretation to create original works of art." Yonder biology

"GeneticPhotos was born thanks to the dream of a group of designers, ARTISTS and SCIENTISTS from Spain with over 10 years experience, who were seeking to show to the world the merger of art and genetics. To merge your DNA and art we have the support of scientific and technical laboratories, CAGT GENETIC ANALYSIS CENTRE and together we have achieved a result that leaves no one indifferent, we encourage you to explore and discover it for yourself." GeneticPhotos

"Head Scientist Vern Muir overseas [sic] each procedure from extracting your DNA, producing your profile before working with our design team to elegantly deliver your artwork." DNA Effect

DNA Portraits Highlight Both Genetic and Aesthetic Options.

A specific number of genetic trait options are provided; aesthetic options are "numerous," "limitless" and "unlimited."
"You can select from two packages: Personal or Sports. Each package analyses five traits of interest, giving a distinctive, interpretable and unique banding pattern that we decipher to tell you your 'type' for each trait." PlayDNA

"At GeneticPhotos we analyse 15 standard polymorphic segments to allow for the high variation existing between each person." geneticphotos.com

"The tough part is choosing the style, color, size and frame from an almost limitless range of possibilities." DNA11

“Unlimited options make your art piece even more customized." DNA11

\section{Discussion}

DNA portraits embody the complex negotiations of science and culture. People are not marketed to as "mere consumers"; DNA portraits could not be sold if we didn't understand something about DNA. Reconsidering what Zwart posited, "[a]re the individuals involved the subjects of new practices of Self-formation, or rather the objects of marketing strategies, that is: mere consumers of novel genomic products?", [Zwart, 2009] the results support that those involved are neither subjects nor objects, but participants, both engaging, and not engaging, with popular concepts of genetic information.

The websites reveal two categories of essential elements that are "sold" to the consumer: the qualities of those portrayed and the "fun" of celebrations of uniqueness, self discovery and family; and the qualities of the companies as "portrayers," their technological and scientific expertise, unique combinations of science and art, and the interior environments they augment. There is a risk in these findings that through the celebration of uniqueness and self discovery, and the advancement of scientific expertise to create adornments for interior environments, that DNA portraits mystify rather than explain science. These 
findings raise important considerations for how scientific processes are communicated, how scientific products are interpreted, and how "art" is defined in the commercial context. 1) What are DNA portraits portraying in terms of identity? and 2) Are commercial DNA portraits "art" and how does this definition influence the technoself?

\subsection{DNA portraits and identity}

There is a tone of "fun" and "play" in how these companies describe the work itself: "We make it fun and effortless" states DNA11 in their description of entering into the processes of DNA extraction and replication. This approach is in contrast to the challenges that the companies marketing genetic testing have faced in terms of ethical, legal and social issues [Auffray et al., 2012]: DNA portraits are guaranteed $100 \%$ satisfaction, and the genetic traits represented are extolled as unique and important to the characteristics of oneself and of the art. The acceptance of the visual results are consistently presented as a "favorable" representation of oneself. Despite the challenges of genetic information mined and sold in reference to disease [Einsiedel and Geransar, 2009], DNA portraits celebrate genetics as positive in whatever form it takes. For example, DNAPlay's options of five "personal" or "sport" characteristics are interpreted as favorable in whatever genetic expression they may take: "Sam was intrigued to learn that she has a less than ideal DNA Sports Portrait... She assures us that this is evidence enough that the environment you grow up in is as important, if not more important, than the genes you inherit" (PlayDNA). The completed image is in turn an identity piece celebratory of the person and their sense of genetic connection and history rather than simply demonstrative of the science behind the traits provided. The promotional techniques of the websites reflect an alternative form of interpretation to the moral debate and disease decisions described in the literature [ten Have, 2001]. By representing "other" biological aspects of the person rather than disease, DNA portraits present other ways of considering "self" in relation to science culture. Company websites and promotional materials are also open to describing the "limits" to the information provided: "Aside from seeing similarities with your relatives (which is very cool and fun by the way), very little can be gleaned from these gel images" (Yonder biology). These are not singular descriptions of the authority of the human genome, but promotions emphasizing that individuals are allowed to interpret genetic information in a way that complements the formation of their own identity. It will therefore be interesting to watch the cost of techniques such as DNA sequencing or microarray, and what happens if and when they become more affordable. Will they be celebrated as "art" as the DNA portraits described in this paper have been, or will the complexity and expansiveness of the information provided remain in the realm of disease research, gene expression profiling and forensic analysis?

DNA portraits are promoted as providing an engagement with the processes of scientific research, a reprieve from the "seriousness" of science practices that are immersed in expectations for results, and the monetary importance of future solutions. Public interest in DNA portraits is part of the present; the results of laboratory processes are relevant to current representations of human identity, and in turn, make science accessible and "human." The concept of the person as "portrayed" and the company as "portrayer" make this a traditional study of a 
portrait [van Alphen, 1997]. Yet presentations of the DNA portrait remain largely fixed in an early concept of DNA that reduces people to their codes. This contrasts with the postgenomic age and postgenomic research that includes among other qualities, the "abandonment of simple views of the gene and of gene action" [Richardson, 2011]. Abandoning simple views means postgenomic research embraces "abundant discourse about the power of genes" and "the nearing of genomics to the clinic and to the consumer" [Richardson, 2011]. Transitioning definitions for postgenomics also allow a fluid concept of the technoself which present DNA portraits as effective commercial bio-art-identity products. The concept of the technoself participates in the sales strategy, furthering uniqueness through visual difference and aesthetic choice. The portraits are a contemporary way to materially engage with an era of scientific and medical exploration.

Identities are promoted through science processes at the microscopic level of DNA code, and are also played out and reimagined in the public sphere [Joselit et al., 2000]: DNA portraits support that people "think through, with, and alongside media" [Hayles, 2012] and that what "media" is and represents is performed and practiced [Couldry, 2004; Postill, 2010; Warde, 2005]. The portraits are also part of the visual practices of daily lives [Grasseni, 2007; Herzfeld, 2007; Pink, 2004], and welcomed into homes and offices where they become part of daily visual routines. DNA portraits parallel the narratives of popular media coverage and TV shows such as CSI, where one of the companies featured in this article, DNA11, has also been seen. Popular forensic crime shows such as CSI have been shown to depict DNA testing as "routine, swift, useful, and reliable," at times presenting "more complex ways of thinking about DNA testing and genetics" [Ley, Jankowski and Brewer, 2012]. DNA portraits are a nod to the now widespread recognition and understanding of DNA: "We are authors of new types of biographies, but also temporary outcomes or products of new discursive pathways" [Zwart, 2009]. DNA portraits, as other technologies [Turkle, 1995; Hayles, 2012] may be the "comprehensive view" that Zwart describes: objects that transcend genomics and identity formation primarily because identity is formed and reformed, responsive to a "temporal fluidity" [Harrison, 2002; Slater, 1995] that is part of communicating and presenting the technoself.

\subsection{Are commercial DNA portraits "art" and what does the answer mean for the technoself?}

The laboratory processes used to create DNA portraits have a long historical development [Rabinow, 1996]. Companies help ease concerns about the "foreignness" of the lab by building impressions of the straightforwardness of the process: "Easy. Painless. Simple" (DNA11.com). The technologies and efforts of the laboratory procedures disappear behind the completed image.

The question as to whether or not DNA portraits are "art" is important for the range of critical thought about technology and identity that the art described in the literature review presents. The artistic activities described in the literature review contrast with the taken-for-granted acceptance and celebration of the products displayed on the DNA portrait sites primarily because the products sold lack critical thought. The results of this study support a redefinition of "DNA portraits" as neither "science," nor "art," but for lack of a better term, as part of a contemporary understanding of technology: "a comprehensive term for complex 
systems of machines and techniques" [Nye, 2007], or, "the application of scientific knowledge for practical purposes" [Stevenson and Lindberg, 2010]. Like technologies that are gradually learned to be taken-for-granted in daily life, commercial products such as the DNA portrait are allowed to become part of the visual scenery, while science and art are required to continually challenge and explore.

The challenge that emerges is not how these products are sold and accepted as identity pieces, but how the technologies are laid bare, as the purchasers themselves participate in established laboratory processes. DNA portraits engage with the aesthetics of commercial material processes that are far removed from the complexities of contemporary understandings of DNA and identity and are instead integrated into contemporary visual meaning. DNA portraits are a representation of self as much as they are a representation of who one is genetically. They are also portions of the histories of bodies, wet labs, digital labs, science and art. Using established biotechnological processes as part of contemporary images and identity-making is part of an "aesthetic monoculture" [Hauser, 2008]. DNA portraits are a form of synecdoche, where parts of creative laboratory production represent much larger and more complex areas of progress and potentials. DNA representations are part of the "postgenomic turn" described as a thoroughly visual turn" that engages with a "continuity of movement that constitutes life processes" [Landecker, 2012]. The perceived simplicity of the image-making processes, and the invisibility of technological histories, simplifies the product, but in the making and remaking of the technoself, only momentarily.

\section{Conclusion}

Practitioners in the fields of arts and science have built on the processes of DNA fingerprinting to develop new products and present new ways of thinking about genetics and identity. Based on gel electrophoresis, the DNA portrait sold as commercial product is one such development. An examination of how DNA portraits are marketed online provides a snapshot of what form biological knowledge and processes take in order to be promoted as acceptable pieces to integrate into consumers' daily material lives. The online promotional environment of DNA portraits promises an avenue of self discovery, a celebration of both uniqueness and familial ties. These promotional techniques also emphasize technological and scientific expertise, a distinct combination of science and art, and participation in sophisticated design environments, bringing laboratory to display in living rooms and kitchens. Ultimately, DNA portraits present the human self at the blurred boundaries of technology, design, taste, and science understanding. DNA portraits, accepted as part of our daily lives, are also removed from the critical interpretations of DNA and identity, potentially mystifying rather than helping to explain science. They are very much an "identity" product of the genomic times, a representation of the technoself not possible without sequencing technology or some basic understanding of DNA. York, U.S.A.: Cold Spring Harbor Laboratory Press.

Annas, G. and Elias, S. (2014). '23andMe and the FDA'. New England Journal of Medicine 370 (11), pp. 985-988. 
Auffray, C., Caulfield, T., Khoury, M. J., Lupski, J., Schwab, M. and Veenstra, T. (2012). 'Looking back at genomic medicine in 2011'. Genome Med. 4 (1), p. 9.

CAE (1987). 'Critical Art Ensemble'. URL: http://www . critical-art .net (visited on 15th February 2015).

Chial, H. (2008). 'DNA sequencing technologies key to the human genome project'. Nature Education 1 (1), p. 219.

Couldry, N. (2004). 'Theorising media as practice'. Social Semiotics 14 (2), pp. 115-132.

Daemmrich, A. (1998). 'The evidence does not speak for itself expert witnesses and the organization of DNA-typing companies'. Social Studies of Science 28 (5-6), pp. 741-772.

Davis, A. (2013). 'The xenotext: Creating the poetry bug'. Maclean's, 11th January 2013. URL:

http://www.macleans.ca/culture/books/creating-the-poetry-bug/ (visited on 20th August 2014).

Davis, J. (1996). 'Microvenus'. Art Journal 55 (1), pp. 70-74.

Delgado, A. (2013). 'DIYbio: Making things and making futures'. Futures 48, pp. 65-73.

Douglas, S., Dietz, H., Liedl, T., Högberg, B., Graf, F. and Shih, W. (2009). 'Self-assembly of DNA into nanoscale three-dimensional shapes'. Nature 459 (7245), pp. 414-418.

Einsiedel, E. and Geransar, R. (2009). 'Framing genetic risk: Trust and credibility markers in online direct-to-consumer advertising for genetic testing'. New Genetics and Society 28 (4), pp. 339-362.

FDA (2013). 23andMe, Inc. 11/22/13. Public Health Service, Food and Drug Administration.

Fornaciari, F. (2013). 'The language of technoself: Storytelling, symbolic interactionism'. In: Handbook of Research on Technoself: Identity in a Technological Society, pp. 64-83. DOI: 10.4018/978-1-4666-2211-1.ch004.

Grasseni, C. (2007). Skilled visions: Between apprenticeship and standards. Oxford, U.K.: Berghahn Books.

Harrison, B. (2002). 'Photographic visions and narrative inquiry'. Narrative inquiry $12(1)$, pp. 87-111.

Hauser, J. (2008). 'Observations on an Art of Growing Interest'. In: Tactical Biopolitics. Ed. by B. Da Costa and K. Philip, p. 83.

Hayles, N. (2012). How we think: Digital media and contemporary technogenesis. Chicago, U.S.A.: University of Chicago Press.

Heim, W. (2004). Critical Art Ensemble. Enterchange. Online Exhibition of Performance and Nature. [online]. URL:

http://greenmuseum.org/c/enterchange/artists/cae/ (visited on 18th February 2015).

Herzfeld, M. (2007). 'Envisioning skills: Insight, hindsight, and second sight'. In: Skilled visions: Between apprenticeship and standards. Ed. by C. Grasseni. Oxford, U.K.: Berghahn Books, pp. 207-218.

Hilgartner, S. (2012). 'Novel constitutions? New regimes of openness in synthetic biology'. BioSocieties 7 (2), pp. 188-207.

Hunter, D., Khoury, M. and Drazen, J. (2008). 'Letting the genome out of the bottle-will we get our wish?' New England Journal of Medicine 358 (2), pp. 105-107.

Jeffreys, A., Wilson, V. and Thein, S. (1985). 'Hypervariable'minisatellite'regions in human DNA'. Nature 314, pp. 67-73. 
Joselit, D., Baker, C., Critical Art Ensemble, Hayles, N., Larson, E., Millner, S. and Wieczorek, M. (2000). 'Biocollage'. Art Journal 59 (3), pp. 44-63.

Kac, E. (2000). GFP bunny [genetics]. URL: http://www. ekac.org/transgenicindex.html (visited on 15th February 2015).

Kean, S. (2011). 'A lab of their own'. Science 333 (6047), pp. 1240-1241.

Kemp, M. (2003). 'The Mona Lisa of modern science'. Nature 421 (6921), pp. 416-420.

LaBean, T. (2009). 'Nanotechnology: Another dimension for DNA art'. Nature 459 (7245), pp. 331-332.

Landecker, H. (2012). 'The Life of Movement: From Microcinematography to Live-Cell Imaging'. Journal of Visual Culture 11 (3), pp. 378-399.

Landrain, T., Meyer, M., Perez, A. and Sussan, R. (2013). 'Do-it-yourself biology: Challenges and promises for an open science and technology movement'. Systems and Synthetic Biology 7 (3), pp. 115-126. DOI: 10.1007/s11693-013-9116-4.

Levitt, D. (2001). 'Let the consumer decide? The regulation of commercial genetic testing'. Journal of Medical Ethics 27 (6), pp. 398-403.

Ley, B., Jankowski, N. and Brewer, P. (2012). 'Investigating CSI: portrayals of DNA testing on a forensic crime show and their potential effects'. Public Understanding of Science 21 (1), pp. 51-67.

Luppicini, R. (2013). 'The emerging field of technoself studies (TSS)'. In: Handbook of Research on Technoself: Identity in a Technological Society, pp. 1-25. DOI: 10.4018/978-1-4666-2211-1. ch001.

Manglano-Ovalle, I. (2006). Portrait of a Young Reader. Bronx Library Center.

Marwick, A. (2011). 'I tweet honestly, I tweet passionately: Twitter users, context collapse, and the imagined audience'. New Media \& Society 13 (1), pp. 114-133.

Müller, U. and Nicolau, D. (2005). Microarray technology and its application. Springer.

National Geographic (2014). 'The genographic project'. URL: https: //genographic . nationalgeographic. com (visited on 11th July 2014).

Nelkin, D. and Lindee, S. (1995). The DNA mystique. New York, U.S.A.: WH Freeman \& Company.

Newman, S. (2012). 'Synthetic biology: life as App store'. Capitalism Nature Socialism $23(1)$, pp. 6-18.

Nye, D. (2007). Technology Matters. Cambridge, Massachusetts, U.S.A.: The MIT Press.

Peters, J. (1999). Speaking into the air: A history of the idea of communication. Chicago, U.S.A.: University of Chicago Press.

Pink, S. (2004). Home truths: Gender, domestic objects and everyday life. Oxford, U.K.: Berg.

Postill, J. (2010). 'Introduction: Theorising media and practice'. In: Theorising Media and Practice. Ed. by B. Bräuchler and J. Postill. Oxford and New York: Berghahn, pp. 1-32.

Rabinow, P. (1996). Making PCR: a story of biotechnology. Chicago, U.S.A.: University of Chicago Press.

Richardson, S. (2011). 'What is postgenomics? [Abstract]'. URL: http://citation.allacademic.com/meta/p508815_index.html (visited on 19th July 2014).

Rosen, J. (2009). 'Genetic surveillance for all'. Slate. URL: http://www.slate.com/articles/news_and_politics/jurisprudence/2009/ 03/genetic_surveillance_for_all.html (visited on 17th August 2014). 
Rothemund, P. (2006). 'Folding DNA to create nanoscale shapes and patterns'. Nature 440 (7082), pp. 297-302. DOI: 10.1038/nature04586.

Schmidt, M. (2009). 'Special issue: Societal aspects of synthetic biology'. Systems and Synthetic Biology 3 (1-4), pp. 1-2.

Seeman, N. (2003). 'DNA in a material world'. Nature 421 (6921), pp. 427-431.

Slater, D. (1995). 'Domestic photography and digital culture'. In: The photographic image in digital culture. Ed. by M. Lister. London, U.K.: Routledge, pp. 129-146.

Stevenson, A. and Lindberg, C. (2010). New Oxford American dictionary. Oxford; New York: Oxford University Press.

Templeton, N. (1992). 'The Polymerase Chain Reaction History Methods, and Applications'. Diagnostic Molecular Pathology 1 (1), pp. 58-72.

ten Have, H. (2001). 'Genetics and culture: the geneticization thesis'. Med Health Care Philos 4 (3), pp. 295-304.

Thomas, B. (2009). 'Portrait/icon/code: Marc Quinn's DNA Portraits and the Imaging of the Self'. Thesis. U.S.A.: University of Georgia.

Turkle, S. (1995). Life on the screen: Identity in the age of the Internet. New York, U.S.A.: Simon \& Schuster.

van Alphen, E. (1997). 'The portrait's dispersal: Concepts of representation and subjectivity in contemporary portraiture'. In: Portraiture: Facing the Subject. Ed. by J. Woodall. Manchester, U.K.: Manchester University Press, pp. 239-256.

Vanous, P. (2009). Latent figure protocol. 2007-2009 [gel electrophoresis]. URL: http: //paulvanouse.com/lfp2.html (visited on 15th February 2015).

Walters, H. (2013). 'A DNA portrait from a single hair: The work of Heather Dewey-Hagborg'. TED, 20th June 2013. URL: http://ideas.ted.com/2013/06/20/generating-a-sculpture-from-a-hairthe-work-of-heather-dewey-hagbor (visited on 17th August 2014).

Wang, L. (2013). 'Guarding Our DNA'. Chemical \& Engineering News 91 (25), pp. 33-33.

Warde, A. (2005). 'Consumption and theories of practice'. Journal of Consumer Culture 5 (2), pp. 131-153.

Zettler, P., Sherkow, J. and Greely, H. (2014). '23andMe, the Food and Drug Administration, and the future of genetic testing'. JAMA Intern. Med. 174 (4), pp. 493-494.

Zwart, H. (2009). 'Genomics and identity: The bioinformatisation of human life'. Med Health Care Philos 12 (2), pp. 125-36.

Author

Meaghan Brierley (Ph.D. in Communication Studies, University of Calgary, 2013) is a postdoctoral scholar at the Calgary Institute for the Humanities. In addition to her research activities, Brierley is assistant book review editor for the journal Science and Public Policy and continues a professional practice of biomedical illustration. E-mail: m.brierley@ucalgary.ca.

How to cite NoDerivativeWorks 4.0 License.

ISSN 1824 - 2049. Published by SISSA Medialab. http:/ /jcom.sissa.it/. 